\title{
Controlling fusarium head blight of wheat (Triticum aestivum L.) with genetics ${ }^{*}$
}

\author{
Li Zhang ${ }^{1,2}$, Peigao Luo ${ }^{1}$, Zhenglong Ren ${ }^{1}$, Huaiyu Zhang ${ }^{2}$ \\ ${ }^{1}$ State Key Laboratory of Plant Breeding and Genetics, Sichuan Agricultural University, Ya'an, China; \\ ${ }^{2}$ College of Life and Science, Sichuan Agricultural University, Ya'an, China. \\ E-mail:1pg052000@yahoo.com.cn
}

Received 12 May 2011; revised 7 July 2011; accepted 20 July 2011.

\begin{abstract}
Fusarium head blight, one of the most destructive diseases of wheat (Triticum aestivum L.), results in significant economic losses from reduced grain yield and quality. In recent decades, the disease has been frequently recorded, especially under warm and wet climatic conditions. Genetic resistance has engaged plant breeders because the use of resistant cultivars is the most economical, effective, and environmentally friendly method of control. In the present paper, we summarize the research on resistance genetics of $\mathrm{Fu}$ sarium head blight, suggest a new method for evaluating Fusarium head blight resistance, and recommend strategies for creating and developing new sources of resistance to Fusarium head blight through the use of alien genes and chromosomal segments.
\end{abstract}

Keywords: Fusarium Head Blight; Triticum aestivum L.; Resistance Evaluation; Alien Species

\section{INTRODUCTION}

Fusarium head blight (FHB), also called ear blight or head scab, is caused by Fusarium spp. and is one of the most destructive diseases of wheat (Triticum aestivum L.). FHB occurs primarily in warm and humid climatic conditions during the flowering stage [1,2]. Diseased spikes show premature bleaching and produce shriveled kernels, leading to large yield losses [3]. Worse yet, FHB can cause quality reduction as a result of contamination by trichothecene mycotoxins, which are detrimental to the health of both humans and domestic animals $[4,5]$. With its frequent incidence and the expansion of the infected area, FHB has grown in importance to plant breeders and pathologists.

Several review articles on wheat FHB have been pub-

*Applicable sponsors: Ministry of Science Technology of China (Nos. 30971787) and Huoyindong Education Foundation for Younger Teacher (Nos.11030). lished with different foci, including conventional breeding and FHB resistance improvement $[1,3,6-8]$, the occurrence scope and the significance of mycotoxins $[9,10]$, the interaction mechanisms between host and pathogens [11], molecular markers for FHB resistance genetics [12], an alien gene library for enhancing resistance [13], and the main available Quantitative traits loci (QTL) $[14,15]$. To date, there has been no review of the methods for quickly and accurately evaluating genetic resistance or for effectively developing new FHB-resistant lines for wheat breeding. Therefore, this article has three objectives: 1) to summarize and update current knowledge on FHB, 2) to discuss methods for evaluating resistant cultivars and provide suggestions for establishing an evaluation system, and 3) to describe new methods of wheat resistance improvement using the alien gene library.

\section{THE PATHOLOGY OF FHB}

The prevalence of FHB, caused by various fungi, is closely associated with favorable environments. Nineteen species of Fusarium are reported to cause wheat FHB disease [4]. In general, F. culmorum, F. avenaceum (teleomorph Gibberella avenacea), and especially F. graminear (teleomorph G. zeae), appear most common in nature $[1,3]$. Studies show that F. graminear is the predominant pathogen causing FHB under warmer, humid conditions found in China, Canada, Australia, Central Europe and parts of the wheat-growing area in the United States; that F. culmorum, F. avenaceum, F. sporotrichioides and $F$. langsethiae are the main pathogens in cool and wet/humid conditions, and that $F$. poae may be the most important pathogen in warmer and drier environments $[8,16]$. This suggests that environmental factors, besides the genetic diversity of the pathogens, may explain the distribution of FHB because different species of pathogens, or strains of the same species under different conditions, would infect different parts of wheat plants during various developmental stages. 


\subsection{FHB Development and Prevalance}

The source of primary inoculation is the fungal colonies overwintering on crop residues such as wheat, maize, and rice [1,17-20], so that FHB usually occurs in wheatwheat, corn-wheat, or rice-wheat rotations [21-24]. The pathogens spread mainly via the dispersal of conidia that are blown or splashed to new infection sites [8,25].

Wheat is most susceptible to infection during anthesis, after which susceptibility declines sharply [26]. Later infections may lead to deoxynivalenol (DON) accumulation despite the absence of visible symptoms, especially under conditions of prolonged wetness during the hard dough stage [27]. The occurrence and development of this disease are significantly associated with temperature and humidity [16,28]. Anderson[14] found incidence increases as temperature increases from $20^{\circ} \mathrm{C}$ to $30^{\circ} \mathrm{C}$, and little or no infection occurred under $15^{\circ} \mathrm{C}$. Humidity is as important as temperature for the occurrence of wheat scab $[8,25,29,30]$. Infection in different stages has different effects on both yield and quality reduction, and various climatic factors have different effects on infection at different wheat growth stages, which may be responsible for the difficulty in controlling infection.

\subsection{FHB Reduce Wheat Yield and Quality}

FHB causes about $10 \%$ - 70\% yield loss during epidemic years [31]. In China, FHB has been found in $2 / 3$ of provinces, with more than 7 million hectares of wheat-growing areas affected and yield losses of more than 1 million tons in epidemic years [32,33]. In the United States, severe FHB outbreaks during the 1990s resulted in a total economic loss of about \$3 billion [34]. In Canada, HB epidemics occurred about once every 9 years from 1927 to 1980 [3]. Clearly, FHB has been a major disease threatening wheat yields [20,35-37].

In addition, various Fusarium species are capable of producing mycotoxins in corn. Over 20 mycotoxins are produced by Fusarium species, and the dominant mycotoxin is DON and its derivatives [4]. DON can be translocated within the wheat head via xylem and phloem and accumulated in cells [38]. DON levels are strongly influenced by host genotype as well as weather later in the grain fill period. Higher DON accumulates with extended periods of moisture post-anthesis $[39,40]$. However, some host genotypes react to prolonged exposure to moisture with a decrease in DON content [41]. These genotypes produce "premature spikes" with the upper portion wilted, leading to bleaching and yield reduction, but are not colonized by the fungus, so DON content is reduced [4]. DON not only plays an important role in fungal spreading and disease development but also threatens human and livestock health with microdosis $[9,42]$. DON present in food at $\mathrm{mg} / \mathrm{kg}$ can cause vomiting, diarrhea, fever and other symptoms of acute poisoning in humans and animals, and it is also closely correlated with anemia, immuno-suppression, and cancer $[43,44]$. Many countries have established maximum allowed levels of DON in cereal and cereal products to protect humans and animals from mycotoxicosis [15-45].

Food production and safety is a society-wide concern, so it is important to control FHB disease and minimize risks to humans and livestock. Control of wheat FHB can be approached from aspects of both the pathogen and the host.

\section{PATHOGEN CONTROL}

Preventing contamination of seeds and soil by Fusarium species can reduce the occurrence of FHB [46]. Rotation with non-host crops, removal of infected residue and seed-treatment fungicide can effectively reduce primary inoculation $[3,20]$. However, these methods cannot efficiently control FHB because of the large influx of inoculum later in the growing season. Anthesis-treatment fungicides are considered to be the most effective measure against FHB and DON accumulation in many trials [47-49]. However, fungicide application alone is often not sufficient to reduce FHB and DON accumulation, and results vary among studies [47,50,51]. In addition, fungicide abuse can result in pathogen tolerance and environmental problems [52,53]. Therefore, fungicides should generally not be used if control is not urgent or when host resistance alone could be effective.

\subsection{Resistant Cultivars}

Since Arthur [18] first found differences in scab-resistance among different germplasms, finding and creating scab-resistant cultivars has been considered the most economical and effective method for controlling FHB and DON [1].

Only a few scab-resistant germplasms have been used in breeding for FHB-resistant wheat, including Sumai 3, Wangshuibai and Ning 7840 from China; Nobeokabouzu from Japan; Frontana from Brazil and Praa 8 and Novokrumka from Europe [54]. Sumai 3 is the most successful and widely used scab-resistant germplasm in breeding programs $[15,55]$. However, most wheat cultivars are susceptible or mildly susceptible to FHB while no cultivars are immune to this disease [56,57]. Identifying and developing new sources of scab-resistant cultivars is the most important task in future breeding efforts.

\subsection{Methods for Evaluating Host Resistance}

Screening new resistant germplasms is a prerequisite for developing new resistant cultivars, and a quick and effective method for evaluating $\mathrm{FHB} / \mathrm{DON}$ resistance is 
very important in screening new germplasms.

Schroeder and Christensen [58] identified two types of resistance: Type I, resistance to primary infection, usually measured by counting infected spikelets 7 to $21 \mathrm{~d}$ after spraying inoculation, and Type II, resistance to disease spread, characterized by infected spikes after point inoculation. Three additional types of resistance have been identified: Type III, resistance to DON accumulation [59,60]; Type IV, resistance to kernel infection; and Type $\mathrm{V}$, resistance to yield loss [6,11]. The last two types are rarely used because of unclear mechanisms and concepts of disease resistance. Type I and Type II resistance are the present main evaluation systems, but they are morphological traits that strongly depend on the subjective interpretation of the observer. Type III is a quantitative method based on measuring DON concentration rather than on observing symptoms. However, DON can be both a consequence of pathogen invasion and a virulence factor for disease development [61,62], and the associations between pathogen invasion, DON, and disease spread are highly variable and fairly complex [63]. Thus, none of the existing methods for identifying FHB resistance in wheat are completely reliable.

Establishment of a quantitative method based on measuring a hall marker during the host-pathogen interaction process would play a key role in screening for resistant germplasms. For example, a pathogen of host tissue is probably facilitated by the vast array of hydrolyzing enzymes secreted by Fusarium and develops when the plant cuticle is degraded by the cutinase/lipases secreted by Fusarium [2]. The infected wheat cell wall, membrane and even the mitochondria and chloroplasts are damaged [64,65], infected spikelets show premature bleaching and their ability to photosynthesize is reduced or lost, resulting in yield loss. In this process, the hydrolyzing enzymes, cutinase, lipases, and photosynthetic parameters are at different levels for different cultivars, and these varying levels can be used to evaluate FHB resistance. In addition, some complexes in plants, like phytoanticipins, cyclic hydroxamic acids and phenolics $[66,67]$ in wheat that can inhibit the growth of Fusarium pathogens can also be used to evaluate FHB resistance.

\subsection{Genetic Control for FHB}

FHB resistance is a quantitative trait controlled by multiple genes, making it difficult to determine resistance mechanisms and breed resistant cultivars. With the development of a molecular marker and marker map, QTLs for FHB resistance have been identified. Anderson and Buerstmary et al. reviewed the stable QTLs for FHB resistance found by previous research $[14,15]$. QTLs for FHB disease were found on all wheat chromosomes except chromosome 7D [15].
Different cultivars appear to have their own FHB QTLs on chromosomes, so crosses between these cultivars may yield transgressive progeny with FHB resistance [3]. Unfortunately, the resistant cultivars are usually accompanied by poor agronomic traits. As a result, transgressive lines are often selected from crosses between two moderately susceptible parents with good agronomic characters or from crosses between a resistant cultivar and a susceptible cultivar with superior agronomic traits in the breeding process $[4,68]$. This approach results in many new resistant germplasms. Most FHB-resistant lines are from crosses between Sumai 3 and other cultivars with good agronomic traits. Therefore, it is important to identify FHB-resistant cultivars other than Sumai 3 in order to diversify the gene pool of wheat FHB resistance.

\subsection{Alien Genetic Resources and the Prospect of Wheat FHB Resistance Improvement}

A number of relatives of wheat have been identified as resistant to FHB since the $1980 \mathrm{~s}$. High resistance to FHB of Elymus giganteus $(2 n=2 x=28, \mathrm{JJNN})$ was reported by Mujeed-Kazi et al. [69] and was confirmed by Wang et al. [70,71] Following this, a large-scale screening of wheat relatives was carried out, and several were found to have high FHB resistance. Relatives of wheat identified as resistant to FHB have various ploidy levels, ranging from $2 x$ to $10 x$. Wan et al. [72] found high resistance was mainly found in perennial genera: Roegneria, Hystrix, Agropyron, Kengyilia and Elymus, with some species' resistance even exceeding that of Sumai 3 [13]. Fedak [73] reported that the native Japanese species $E$. humidus was immune to FHB. These related species can be novel sources of FHB-resistant genes, which would be useful for FHB resistance improvement in wheat.

It is worthwhile to consider how to use the alien gene library. Alien chromatin genes can usually be incorporated in cultivated wheat through chromosome amphiploids, addition, substitution and translocation because wheat is allopolyploid [74]. Several hundred alien chromosomal fragments with FHB resistance have been successfully integrated in wheat, including fragments from Triticum macha, Elytrigia intermedia, Thinopyrum ponticum, Elymus racemifar, Roegneria kamoji and Leymus racemosus [74-80].

Wheat-alien amphiploid lines contain the genomes of both wheat and the alien species. Wheat-alien addition and substitution lines carry a whole alien chromosome on a wheat genetic background through chromosome addition and substitution, respectively. All of the amphiploid, addition and substitution lines carry a large number of unwanted genes in addition to FHB-resistant genes. Moreover, chromosome instability and linkage 
drag on the individual alien chromosomes and meiotic lines in breeding limit the utilization of addition and substitution lines [13]. Therefore, it is difficult for breeders to directly use amphiploids, addition and substitution lines in breeding programs. Wheat-alien translocation only carries an alien chromosome segment connected with a wheat chromosome, which reduces the presence of unwanted genes and linkage drag. In addition, the wheat portion of a translocated chromosome in the translocation lines can recombine with a corresponding wheat chromosome, ensuring chromosome stability. Therefore, wheatalien translocation is the most effective approach for introducing FHB-resistant genes from alien species, integrating alien chromosomal fragments that carry the resistant genes without conferring significant linkage drag on wheat genomes [13].

Most of the wheat-alien translocations currently in use are large fragment translocations containing many garbage genes that may threaten normal wheat growth. Small chromosome segment translocation reduces the number of unwanted genes as much as possible, leading, for example, to a successful wheat-rye cross with the induction of the genetic instability of the monosomic addition of a rye chromosome [81]. Traits of interest can be transferred to the recipient crop without cytological changes in its genomic constitution [82], implying that the introgressed chromatin segments are cryptic. This type of translocation, known as cryptic translocation, cannot be detected by cytological techniques, and molecular methods must be used [83]. Although the mechanism for the occurrence of such cryptic translocations is unknown, their occurrence seems frequent [84]. Theoretically, the more of the resistant loci wheat possesses, the stronger the resistance it has. Multiple loci for resistance in cryptic translocations can be adapted well in the wheat chromosomes together and strengthen the resistance of wheat while many larger chromosome translocations cause genetic unbalance. Yu25 (Triticum aestivum, $2 n=6 x=42$, AABBDD) provides an example of a benefit from cryptic translocation, possessing two Pm (powdery mildew) and a $\mathrm{Yr}$ (stripe rust)-resistant gene from Thinopyrum intermedium and exhibiting immunity to powdery mildew and stripe rust [85-87]. Cryptic translocation is a favorable method for incorporating multiple alien genes into wheat. Wheat line 699, derived from crosses of Mianyang11 (MY11)/Yu25, has been identified as immune and nearly immune to both stripe rust and powdery mildew, and highly resistant to FHB [88]. We can conclude that the resistant genes are cryptic translocations from Thinopyrum intermedium because MY11 is susceptible to all three diseases. Resistance screening showed that wheat line 699 has high resistance (Figure 1 and Table 1) and is a novel resource for wheat

\section{FHB resistance.}

Integrating different alien FHB-resistant genes and even multi-fungus resistant genes into wheat is possible because of cryptic translocation. However, cryptic translocation can only be achieved after a long period of breeding, a lot of manpower and financial resources. But if we can find one gene that prevents infection by the pathogens, this problem of long period of breeding can be solved. Though discovery of a germplasm immune to infection with the pathogens is still elusive, reports of a putative $\mathrm{ABC}$ transporter gene that confers durable resistance to multiple fungal pathogens in wheat indicates the possibility of developing and screening new resistant lines [89].

\section{CONCLUSIONS}

FHB is a destructive disease for wheat, which can result in yield loss and produce mycotoxins that threaten human and animal health. Screening and breeding resistant wheat cultivars can stably, effectively and safely guard against FHB compared with cropping measures and fun-

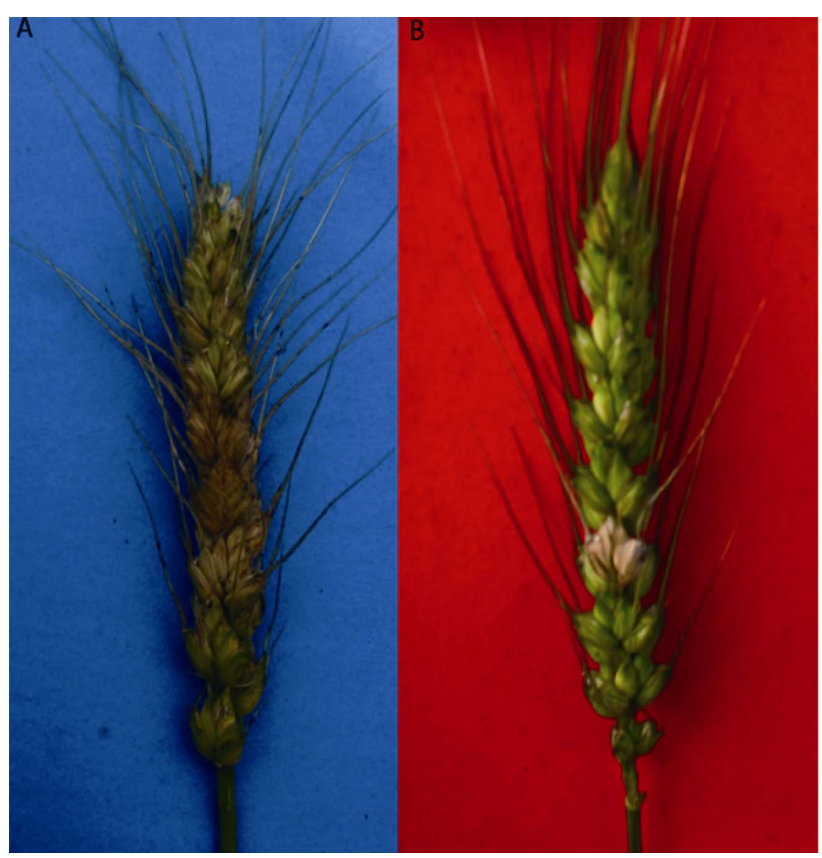

Figure 1. The spikelets of 661 (left) and 699 (right) after 21 days point inoculation.

Table 1. The ratio of infected spikelets of 661 and 69928 days after inoculation.

\begin{tabular}{cccccc}
\hline & Materials & $\begin{array}{c}\text { Plant } \\
\text { tests }\end{array}$ & $\begin{array}{c}\text { infected } \\
\text { spikelets }\end{array}$ & $\mathbf{0 . 0 5}$ & $\mathbf{0 . 0 1}$ \\
\hline Injection & 661 & 166 & 67.18 & $\mathrm{a}$ & $\mathrm{A}$ \\
& 669 & 264 & 10.04 & $\mathrm{~b}$ & $\mathrm{~B}$ \\
Smearing & 661 & 146 & 40.75 & $\mathrm{a}$ & $\mathrm{A}$ \\
& 699 & 254 & 17.77 & $\mathrm{~b}$ & $\mathrm{~B}$ \\
\hline
\end{tabular}


gicide control. FHB/DON resistance evaluation is very important for screening new germplasms. We suggest a quantitative method based on measuring a hall marker during the host-pathogen interaction process such as an enzyme or other complex that has a significant relationship with host FHB resistance. Many relatives of wheat exhibit very high resistance to FHB, and can contribute many novel FHB-resistant genes to wheat. These alien genes can be more effective for resistance compared with limited inherent resistance to FHB. The multiple loci of FHB resistance indicate that wheat-alien translocation (especially cryptic translocation) is the ideal technique for transferring alien genes to wheat chromosomes. In the future, breeders should identify more new alien genes with FHB resistance and utilize cryptic translocation to integrate the genes into the wheat genome for higher FHB resistance. In addition, finding a novel gene with resistance to fungi is important for breeding highly multi- fungus-resistant wheat.

\section{ACKNOWLEDGEMENTS}

We thank members of our laboratories for helpful comments on the manuscript.

\section{REFERENCES}

[1] Parry, D.W., Jenkinson, P. and Mcleod, L. (1995) Fusarium ear blight (scab) in small grain cereal-A review. Plant Pathology, 44, 207-238.

doi:10.1111/j.1365-3059.1995.tb02773.x

[2] Walter, S., Nicholson, P. and Doohan, F.M. (2010) Action and reaction of host and pathogen during Fusarium head blight disease. New Phytologist, 185, 54-66. doi:10.1111/j.1469-8137.2009.03041.x

[3] Bai, G.H. and Shaner, G. (1994) Scab of wheat: Prospects for control. Plant Disease, 78, 760-766. doi:10.1094/PD-78-0760

[4] Stepień, L. and Chelkowski, J. (2010) Fusarium head blight of wheat:pathogenic species and their mycotoxins. World Mycotoxin Journal, 3, 107-119.

[5] Li, X., Zhang, J.B., Song, B., Li, H.P., Xu, H.Q. and Qu B., et al. (2010) Resistance to fusarium head blight and seedling blight in wheat is associated with activation of a cytochrome P450 gene. Phytopathology, 100, 183-191. doi:10.1094/PHYTO-100-2-0183

[6] Mesterhazy, A. (1995) Types and components of resistance to Fusarium head blight of wheat. Plant Breeding, 114, 377-386. doi:10.1111/j.1439-0523.1995.tb00816.x

[7] Miedaner, T. (1997) Breeding wheat and rye for resistance to Fusarium disease. Plant Breeding, 116, 201-220. doi:10.1111/j.1439-0523.1997.tb00985.x

[8] Xu, X.M. and Nicholson, P. (2009) Community ecology of fungal pathogens causing wheat head blight. Annual Review of Phytopathology, 47, 83-103. doi:10.1146/annurev-phyto-080508-081737

[9] Snijders, C.H.A. (1990) The inheritance of resistance to head blight caused by Fusarium culmorum in winter wheat. Euphytica, 50, 11-18. doi:10.1007/BF00023155

[10] Placinta, C.M., D’Mello, J.P.F. and Macdonald, A.M.C. (1999) A review of worldwide contamination of cereal grains and animal feed with Fusarium mycotoxins. Animal Feed Science Technical, 78, 21-37.

[11] Mesterhazy, A., Bartok, T., Mirocha, C.G. and Komorozy, R. (1999) Nature of wheat resistance to Fusarium head blight and role of Deoxynivalenol for breeding. Plant Breeding, 118, 7-110. doi:10.1046/j.1439-0523.1999.118002097.x

[12] Kolb, F.L., Bai, G.H., Muehlbauer, G.J., Anderson, J.A., Smith, K.P. and Fedak, G. (2001) Host plant resistance genes for Fusarium head blight:mapping and manipulation with molecular markers. Crop Science, 41, 611-619. doi:10.2135/cropsci2001.413611x

[13] Cai, X., Chen, P.D., Xu, S.S., Oliver, R.E. and Chen, X. (2005) Utilization of alien genes to enhance Fusarium head blight resistance in wheat-A review. Euphytica, 142, 309-318. doi:10.1007/s10681-005-2437-y

[14] Anderson, J.A. (2007) Marker-assisted selection for Fusarium head blight resistance in wheat. Internation Journal of Food Microbiology, 119, 51-53. doi:10.1016/j.ijfoodmicro.2007.07.025

[15] Buerstmary, H., Ban, T. and Anderson, J.A. (2009) QTL mapping and marker-assisted slection for Fusarium head blight resistance in wheat: A rivew. Plant Breeding, 128 , 1-26. doi:10.1111/j.1439-0523.2008.01550.x

[16] Rossi, V., Ravanetti, A., Pattori, E. and Giosue, S. (2001) Influence of temperature and humidity on the infection of wheat spikes by some fungi causing Fusarium head blight. Journal of Plant Pathology, 83, 189-198.

[17] Adams, J.F. (1921) Observations on wheat scab in Pennsylvania and its pathological histology. Phytopathology, 11, 115-125.

[18] Arthur, J.C. (1891) Wheat scab. Indiana Agriculturat. Experimentat Station Buttetin, 36, 129-138.

[19] Warren, H.L. and Kommedahl, T. (1973) Fertilization and wheat refuse effects on Fusarium species associated with wheat roots in Minnesota. Phytopathology, 63, 103-108. doi:10.1094/Phyto-63-103

[20] Sutton, J.C. (1982) Epidemiology of wheat head blight and maize ear rot caused by Fusarium graminearum. Canadian Journal of Plant Pathology, 4, 195-209. doi:10.1080/07060668209501326

[21] Snyder, W.C. and Nash, S.M. (1968) Relative incidence of Fusarium pathogens of cereals in rotation plots at Rothamsted. Transactions of the British Mycological Society, 51, 17-25. doi:10.1016/S0007-1536(68)80009-9

[22] Hoffer, G.N., Johnson, A.G. and Atanasoff, D. (1918) Corn root rot and wheat scab. Journal of Agriculture Research, 14, 611-612.

[23] Seaman, W.L. (1982) Epidemiology and control of mycotoxingenic Fusaria on cereal grains. Canadian Journal of Plant Pathology, 4, 187-190. doi:10.1080/07060668209501324

[24] Zhu, H. and Fan, Y. (1989). Wheat scab epidemics and efficacy of testing for resistance in field in northern Fujiang Province. Jounal of Jiangsu Agricuture Science, 1, 75-78.

[25] Paul, P.A., El-Allaf, S.M., Lipps, P.E. and Madden, L.V. (2004) Rain splash dispersal of Gibberella zeae wheat canopies in Ohio. Phytopathology, 94, 1342-1349. 
doi:10.1094/PHYTO.2004.94.12.1342

[26] Hart, L., Pestka, J. and Liu, M. (1984) Effect of kernel development and wet periods on production of deoxynivalenol in wheat infected with gibberella zeae. Phytopathology, 74, 1415-1418. doi:10.1094/Phyto-74-1415

[27] Del Ponte, E.M., Fermandes, J.M.C. and Bergstrom, G.C. (2007) Influence of growth stage on Fusarium head blight and deoxynivalenol production in wheat. Journal of Phytopathology, 155, 577-581. doi:10.1111/j.1439-0434.2007.01281.x

[28] Pugh, G.W., Johann, H. and Dickson, J.G. (1933) Factors affecting infection of wheat heads by Gibberella saubinetii. Journal of Agriculture Reseach, 46, 771-791.

[29] Horberg, H. (2002) Patterns of splash dispersed conidia of Fusarium poae and Fusarium culmorum. European Journal of Plant Pathologhy, 108, 73-80. doi:10.1023/A:1013936624884

[30] Paul, P.A., Lipps, P.E., Hershman, D.E., McMullen, M.P., Draper, M.A. and Madden, L.V. (2007) A quantitative review of tebuconazole effect on Fusarium head blight and deoxynivalenol content in wheat. Phytopathology, 97, 211-220. doi:10.1094/PHYTO-97-2-0211

[31] Matthies, A. and Buchenauer, H. (2000) Effect of tebuconazole (Folicur) and prochloraz (Sportac) treatments on Fusarium head scab development, yield and deoxynivalenol (DON) content in grains of wheat following artificial inoculation with Fusarium culmorum. Zeitschrift für Pflanzenkrankheiten und Pflanzenschutz, 107, 33-52.

[32] Wang, Y.Z., Yong, X.N. and Xiao, Q.P. (1982) The improvement of identification techniques of scab resistance of wheat and development of resistant sources. Scientica Agricultura Sinica, 5, 67-77.

[33] Lu, W.Z., Chen, S.H. and Wang, Y.Z. (2001) Reserch on wheat scab. Science Publication House Press Inc., Beijing.

[34] Windels, C.E. (2000) Economic and social impacts of Fusarium head blight: Changing farm and rural communities in the Northern Great Plains. Phytopathology, 90, 17-21. doi:10.1094/PHYTO.2000.90.1.17

[35] Mesterhazy, A. (1987) Selection of head blight resistant wheats through improved seedling resistance. Plant Breeding, 98, 23-36. doi:10.1111/j.1439-0523.1987.tb01086.x

[36] Snijders, C.H.A. (1990) Fusarium head blight and mycotoxin contamination of wheat: A review. European Journal of Plant Pathology, 96, 187-198.

[37] Zhang, Y.J., Fan, P.S., Zhang, X., et al. (2009) Quantification of Fusarium greminearum in harvested grain by real-time polymerase chain reactin to assess efficacies of Fungicides on Fusarium head blight, deoxynivalenol contamination, and yield of winter wheat. Pathology, 99, 95-100.

[38] Kang, Z. and Buchenauer, H. (1999) Immunocytochemical localization of Fusarium toxins in infected wheat spikes by Fusarium culmorum. Physiology Molecule Plant Pathology, 55, 257-288. doi:10.1006/pmpp.1999.0233

[39] Culler, M.D., Miller-Garvin, J.E. and Dill-Macky, R. (2007) Effect of extended irrigation and host resistance on deoxynivalenol accumulation in Fusarium-infected wheat. Plant Disease, 91, 1464-1472. doi:10.1094/PDIS-91-11-1464

[40] Cowger, C., Patton-Özkurt, J., Brown-Guedira, G., et al.
(2009) Post-anthesis increased Fusarium head blight and deoxynivalenol levels in North Carolina winter whaet. Phytopathology, 99, 320-327. doi:10.1094/PHYTO-99-4-0320

[41] Lemmens, M., Scholz, U., Berthiller, F., et al. (2004) The role of resistance to deoxynivalenol in the complex Fusarium head blight resistance complex in wheat. In: Canty, S.M., Boring, T., Wardwell, J. and Wards, R.W., Eds., Proceedings of the 2nd International Symposium on Fusarium Head Blight 2004, East Lansing, 11-15 December 2004, 88.

[42] Langevin, F., Eudes, F. and Comeau, A. (2004) Effect of tricothecenesn produced by Fusariu graminearum during Fusarium head blight development in six cereal species. Europeaon Journal of Plant Pathology, 110, 735-746. doi:10.1023/B:EJPP.0000041568.31778.ad

[43] Pestka, J.J., Zhou, H.R., Moon, Y., et al. (2004) Cellular and molecular mechanisms for immune modulation by deoxynivalenol and other trichothecenes: Unraveling a paradox. Toxicology Letters, 153, 61-73. doi:10.1016/i.toxlet.2004.04.023

[44] Schollenberger, M., Muller, H.M., Rufle, M., et al. (2005) Survey of Fusarium toxins in foodstuffs of plant origin marketed in Germany. International Journal of Food Microbiology, 97, 317-326. doi:10.1016/j.ijfoodmicro.2004.05.001

[45] Nishio, Z., Takata, K., Ito, M., Tanio, M., Tabiki, T. and Yamauchi, H., et al. (2010) Deoxynivalenol distribution in flour and bran of spring wheat lines with different levels of Fusarium head blight resistance. Plant Disease, 94, 335-338. doi:10.1094/PDIS-94-3-0335

[46] Gilbert, J., Conner, R., Femandez, M., McLaren, D. and Woods, S. (2003) Role of spring wheat infested with Fusarium graminearum in spread and development of Fusarium head blight and effects on agronomic performance. Journal of Plant Pathology, 25, 73-81.

[47] Paul, P., Lipps, P., Hershman, D., McMullen, M., Draper, M. and Madden, L. (2008) Efficacy of triazole-based fungicides for fusarium head blight and deoxynivalenol control in wheat: A multivariate meta-analysis. Phytopathology, 98, 999-1011. doi:10.1094/PHYTO-98-9-0999

[48] Pirgozliev, S., Ray, R., Edwards, S., Hare, M. and Jenkinson, P. (2008) Effect of timing of fungicide application on the development of fusarium head blight and the accumulation of deoxynivalenol (DON) in winter wheat grain. Cereal Research Communications, 36, 289-299. doi:10.1556/CRC.36.2008.2.9

[49] Blandino, M. and Reyneri, A. (2009) Effect of fungicide and foliar fertilizer application to winter wheat at anthesis on flag leaf senescence, grain yield, flour bread-making quality and DON contamination. European Journal of Agronomy, 30, 275-282. doi:10.1016/i.eja.2008.12.005

[50] Siranidou, E. and Buchenauer, H. (2001) Chemical control of Fusarium head blight on wheat. Journal of Plant Disease Protection, 108, 231-234.

[51] Wiersma, J.J. and Motteberg, C.D. (2005) Evaluation of five fungicide application timings for the control of leaf-spot diseases and Fusariunhead blight in hard red spring wheat. Canadian Journal of Plant Pathology, 27, 25-27. doi:10.1080/07060660509507190

[52] Miller, J.D. and Trenholm, H.L. (1994) Mycotoxins in Grains. Eagan Press Inc., St. Paul. 
[53] Wolf-Hall, C.E. (2007) Mold and mycotoxin problems encountered during malting and brewing. International Journal of Food Microbiology, 119, 89-94. doi:10.1016/j.ijfoodmicro.2007.07.030

[54] Gilbert, J. and Tekauz, A. (2000) Review: Recent developments in research on Fusarium head blight of wheat in Canada. Canadian Journal of Plant Pathology, 22, 1-8. doi:10.1080/07060660009501155

[55] Del Blanco, I.A., Frohberg, R.C., Stack, R.W., Berzonsky, W.A. and Kianian, S.F. (2003) Detection of QTL linked to Fusarium head blight resistance in Sumai 3-derived North Dakota bread wheat lines. Theoretica and Applied Genetics, 106, 1027-1031.

[56] Rudd, J.C., Horsley, R.D., McKendry, A.L. and Elias, E.M. (2001) Host plant resistance genes for Fusarium head blight: Sources, mechanisms, and utility in conventional breeding systems. Crop Science, 41, 620-627. doi:10.2135/cropsci2001.413620x

[57] Lin, F., Kong, Z.X., Zhu, H.L., Xue, S.L., Wu, J.Z. and Tian, D.G., et al. (2004) Mapping QTL associated with resistance to Fusarium head blight in the Nanda2491 $\times$ Wangshuibai population.I. Type II resistance. Theoretical and Applied Genetics, 109, 1504-1511. doi:10.1007/s00122-004-1772-z

[58] Schroeder, H.W. and Christensen, J.J. (1963) Factors affecting resistance of wheat scab caused by gibberella zeae. Phytopathology, 53, 831-838.

[59] Miller, J. and Arnison, P. (1986) Degradation of deoxynivalenol by suspension culture of the Fusarium head blight resistant wheat cultivar frontana. Canadian Journal of Plant Patholog, 8, 147-150. doi:10.1080/07060668609501818

[60] Wang, Y.Z. and Miller, J. (1988) Effects of Fusariumgraminearum metabolites on wheat tissue in relation to fusarium head blight resistance. Journal of Phytopathology, 122, 118-125. doi:10.1111/j.1439-0434.1988.tb00998.x

[61] Bai, G., Desjardins, A.E. and Plattner, R.D. (2001) Deoxynivalenol-nonproducing Fusarium graminearum causes initial infection, but does not cause disease spread in wheat spikes. Mycopathologia, 153, 91-98. doi:10.1023/A:1014419323550

[62] Eudes, F., Comeau, A., Rioux, S., et al. (2001) Impact of trichothecenes on Fusarium head blight [Fusarium graminearum] development in spring wheat (triticum aestivum). Canadian Journal of Plant Pathology, 23, 318-322. doi:10.1080/07060660109506948

[63] Jansen, C, Wettstein von, D., Schafer, W., et al. (2005) Infection patterns in barley and wheat spikes inoculated with wild-type and trichodiene synthase gene disrupted fusarium graminearum. Proceedings of the National Academy of Sciences of the United States of America, 102, 16892-16897. doi:10.1073/pnas.0508467102

[64] Wojciechowski, S., Chelkowski, J. and Kostecki, M. (1995) Infulence of dexoynivalenol on electrolyte Leakage in cereal seeding leaves. Acta Physiologiae Plantarum, 17, 357-360.

[65] Miller, J.D. and Ewen, M.A. (1997) Toxic effects of deoxynivalenol on ribosomes and tissues of the spring wheat clutivars Frontana and Casavant. Nature Toxins, 5, 234-237. doi:10.1002/(SICI)1522-7189(1997)5:6<234::AID-NT3>
3.0.CO;2-Q

[66] Friebe, A., Vilich, V., Hennig, L., Kluge, M. and Sicker, D. (1998) Detoxification of benzoxazolinone allelochemicals from wheat by Gaeumannomyces graminis var. tritici, G. graminis var. graminis, G. graminis var. avenae, and Fusarium culmorum. Applied Enviromental Microbiology, 64, 2386-2391.

[67] McKeehen, J.D., Busch, R.H. and Fulcher, R.G. (1999) Evaluation of wheat (Triticum aestivum L.) phenolic acids during grain development and their contribution to Fusarium resistance. Journal of Agricultural and Food Chemistry, 47, 1476-1482. doi:10.1021/jf980896f

[68] Bai, G.H., Zhou, C.F., Qian, C.M., et al. (1989) An analysis on combining ability of resistance to scab and other characters in eight wheat cultivars. Journal of $\mathrm{Ji}$ ansu Agricalture Science, 1, 79-83.

[69] Mujeeb-Kazi, A., Bernard, M., Bekele, G.T., et al. (1983) Incorporation of alien genetic information from Elymus giganteus into Triticum aestivum. In: Sakamoto, S. Ed., Proceedings of 6th International Wheat Genetics Symposium, Kyoto, 28 November-3 December 1983, 223-231.

[70] Wang, Y.N., Chen, P.D. and Liu, D.J. (1986) Transfer of useful germplasm from Elymus giganteus L. to Commom wheat .I. Production of (T. aestivum L. cv. Chinese Spring $\times$ E. giganteus) F1. Joural of Nangjing Agriculture University, 1, 10-14.

[71] Wang, Y.N., Chen, P.D., Wang, Z.T., et al. (1991) Transfer of useful germplasm from Elymus giganteus L. to commom wheat. II. Cytogenetics and scab resistance of backcross derivatives. Joural of Nangjing Agriculture University, 14, 1-5.

[72] Wan, Y.F., Yen, C. and Yang, J.L. (1997) The diversity of head-scab resistance in Triticeae and their relation to ecological conditions. Euphytica, 97, 277-281. doi:10.1023/A:1003028324059

[73] Fedak, G. (2000) Sources of resistance to Fusarium head blight. Proceeding of International Symposium on Wheat Improvement for Scab. Resistance, Nangjing, 5-10 May 2000, 4.

[74] Oliver, R.E., Cai, X., Xu, S.S. and Stack, R.W. (2005) Wheat-alien species derivatives: A novel source of Resistance to Fusarium head blight in wheat. Crop Science, 45, 1353-1360. doi: $10.2135 /$ cropsci2004.0503

[75] Ban, T. (1997) Evaluation of resisitance to Fusarium head blight in indigenous Japanese species of Agropyron (Elymus). Euphytica, 97, 39-44. doi:10.1023/A:1003078109694

[76] Han, F.P., Fedak, G., Benbdelmouna, A., Armstrong, K. and Ouellet, T. (2003) Characterization of six wheat $x$ Thinopyrum intermedium derivatives by GISH, RFLP, and Multicolor GISH. Genome, 46, 490-495. doi:10.1139/g03-032

[77] Shen, X., Kong, L. and Ohm, H. (2004) Fusarium head blight resistance in hexaploid wheat (Triticum asetivum)Lophopyrum genetic lines and tagging of the alien chromatin by PCR markers. Theoretical and Applied Genetics, 108, 808-813. doi:10.1007/s00122-003-1492-9

[78] Steed, A., Chandler, E., Thomsett, M., Gosman, N., Faure, S. and Nicholson, P. (2005) Identification of Type I resistance to Fusarium head blight controlled by a major gene located on chromosome $4 \mathrm{~A}$ of Tritium macha. Theoretical and Applied Genetics, 111, 521-529. 
doi:10.1007/s00122-005-2043-3

[79] Chen, P.D., Liu, W.X., Yuan, J.H., Wang, X., Zhou, B. and Wang, S.L. (2005) Development and characterization of wheat-Leymus racemosus translocation lines with resistance to Fusarium Head Blight. Theoretica and Applied Genetics, 111, 941-948. doi:10.1007/s00122-005-0026-Z

[80] Cai, X., Xu, S.S., Oliver, R.E., Zhang, Q., Stack, R.W., Zhong, S., et al. (2008) Alien introgression for FHB resistance in wheat-challenges and strategies. In: Appels, R., Eastwood, R., Lagudah, E., Langridge, P., Mackay, M., McIntye, L. and Sharp, P. Eds., Proceeding of the 11th Wheat Genetics, Sydney, 24-29 August 2008, 716718.

[81] Ren, Z.L. and Zhang, H.Q. (1997) Induction of small-segment-translocation between wheat and rye chromosomes. Science in China (Series C), 40, 322-331.

[82] Multani, D.S., Jena, K.K. and Brar, D.S. (1994) Development of monosomic alien addition lines and introgress of genes from Oryza-australiensis domin to cultivated rice Oryza-sativa L. Theoretical and Applied Genetics, 88, 102-109. doi:10.1007/BF00222401

[83] Kuraparthy, V., Sood, S., Chhuneja, P., Dhaliwal, H.S., Kaur, S., Bowden, R.L., et al. (2007) A cryptic wheat-Aegilops triuncialis translocation with leaf rust resistance gene Lr58. Crop Science, 47, 1995-2003. doi:10.2135/cropsci2007.01.0038
[84] Zamir, D. (2001) Improving plant breeding with exotic genetic libraries. Nature Reviews Genetics, 2, 983-989. doi: $10.1038 / 35103589$

[85] Ma, Q., Luo, P.G., Ren, Z.L., Jiang H.R. and Yang Z.J. (2007) Genetic analysis and chromosoma location of two new genes for resistance to powdery mildew in wheat (Triticum aestivum L.). Acta Agronomica Sinica, 33, 1-8.

[86] Luo, P.G., Luo, H.Y., Chang, Z.J., Zhang, H.Y., Zhang, M. and Ren Z.L. (2009) Characterization and chromosomal location of Pm40 in common wheat: A new gene for resistance to powdery mildew derived from Elytrigia intermedium. Theoretical and Applied Genetics, 118, 10591064. doi:10.1007/s00122-009-0962-0

[87] Luo, P.G., Hu, X.Y., Chang, Z.J., et al. (2009) A new stripe rust resistance gene transferred from Thinopyrum intermedium to hexaploid wheat. Phytoprotection, 90, 57-63.

[88] Zhang, L., Chen, J.B., Yang, J.Z., et al. (2009) Identification of new germplasm of wheat scab resistance. Prcoreeding of the Crop science society of China 2009 Annual Conference Proceedings, Guangzhou, October 2009, 143

[89] Krattinger, S.G., Lagudah, E.S., Spielmeyer, W., Singh, R.P., Huerta-Espino, J., McFadden, H. et al. (2009) A putative $\mathrm{ABC}$ transporter confers durable resistance to multiple fun gal pathogens in wheat. Science, 323, 13601363. doi: $10.1126 /$ science. 1166453 